\title{
Suffocated mothers, stabbed sisters, drowned daughters: when women choose death on Shakespeare's stage*
}

\author{
Elizabeth Mazzola \\ The City College of New York, USA
}

\begin{abstract}
Women who choose death on Shakespeare's stage often overturn ideas about tragedy as well as challenge the politics which establish which lives are worth sacrificing and which ones are not. Radically altering the relation between bios and zoe, female suicides collapse the divisions between things that grow, breathe, and love, and those things that block such living. In this essay, I draw on thinking about biopolitics along with feminist readings of Shakespeare in order to explore how characters like Goneril, Gertrude, and Juliet refuse the rules which determine how women's blood must flow or be shed.
\end{abstract}

KEYWORDS: bios and zoe; female suicides; Shakespeare; tragic heroines; Goneril, Gertrude, Juliet, Ophelia, Cleopatra; Antigone.

Madres asfixiadas, hermanas apuñaladas, hijas ahogadas: cuando las mujeres eligen la muerte en el escenario shakesperiano $^{* *}$

RESUMEN: Las mujeres que eligen la muerte en el escenario shakesperiano dan la vuelta a las ideas sobre la tragedia a la vez que desafían la política que establece qué vidas merecen ser sacrificadas y cuáles no. Alterando radicalmente la relación entre bios y zoe, los suicidios femeninos desmantelan las divisiones entre las cosas que crecen, respiran y aman, y aquellas que impiden esa forma de vivir. En este artículo, a partir de lecturas biopolíticas y feministas de Shakespeare, se analiza como algunos personajes, como Goneril, Gertrudis y Julieta rechazan las normas que sam as regras que determinam de que
Mães sufocadas, irmãs esfaqueadas, filhas afogadas: quando as mulheres escolhem a morte no palco shakespeariano ${ }^{* * *}$

RESUMO: Las mulheres que escolhem morrer no palco shakespeariano derrubam ideias sobre a tragédia e desafiam a política que estabelece quais as vidas que vale a pena e quais não vale a pena sacrificar. Ao alterarem radicalmente a relação entre bios e zoe, os suicídios femininos fazem colapsar as divisões entre coisas que crescem, respiram e amam, e as coisas que bloqueiam essa vida. A partir de leituras biopolíticas e feministas de Shakespeare, este ensaio analisa personagens como Goneril, Gertrudes e Julieta e a forma como recu-

\footnotetext{
* I want to thank Carol Thomas Neely and Rob Higney as well as Sederi's anonymous readers for their generous advice and guidance.

** Translation into Spanish by Tamara Pérez-Fernández

*** Translation into Portuguese by Miguel Ramalhete.
}

(5) ederi 29 (2019: 109-33)

https:/ / doi.org/ 10.34136/ sederi.2019.5 
determinan cómo debe fluir o derramarse modo o sangue de mulheres deve fluir ou la sangre de las mujeres.

ser derramado.

PAlabras ClAVE: Shakespeare; bios y zoe; PAlAVRAS-CHAVE: Shakespeare; bios e zoe, suicidios femeninos; heroínas trágicas; suicídios femininos, heroínas trágicas; Goneril; Gertrudis; Julieta; Ofelia; Goneril, Gertrudes, Julieta, Ofélia; Cleopatra; Antígona. Cleópatra; Antígona.

"If all else fail, myself have power to die."

(Romeo and Juliet 3.5.242)

"Ah, women, come we have no friend But Resolution, and the briefest end."

(Antony and Cleopatra 4.15.84-85)

\section{Introduction}

Female deaths on Shakespeare's stage can shut down whatever tragedy aims to elevate, even though our ideas about this genre not only emphasize the agonies of men but also preclude or minimize the suffering of women. Leaves yellow and borrowed robes hang when the great man is brought low, but - to the extent they register in our calibrations of catastrophe-women are typically suffocating, not suffocated, diminished well before the hero totters and falls, and often as not another problem with which he must contend. ${ }^{1}$

In this essay I view female characters' deaths as forms of agency, rebuke, and subtraction, making use of work by philosophers like Giorgio Agamben, Roberto Esposito, and Alain Badiou. Although Shakespeare seems to sequester female suffering and pain, encouraging audiences to view women's agonies as private, smaller, or merely redundant, the deaths of female characters reshape his plays, withdrawing chances for rebirth, redirecting zoe or the life force, and invoking instead what Esposito calls "a right not to be" $(2004,3)$. The order of things or what these thinkers term bios continues to operate afterwards, but opportunities for heroism are collapsed, and the stage from which authority imagines itself emptied out or condemned. A classical pairing sharpens my premise. In Oedipus Rex and Antigone, Sophocles puts a story of female effacement alongside an affirmation of male identity, Antigone's brave choices repeatedly underscored as desperate and

\footnotetext{
${ }^{1}$ References to Shakespeare's plays employ the Norton Shakespeare.
} 
unseen, whereas Oedipus's impulsive actions are depicted as honorable and willed, despite their ignorance, even in their futility. Oedipus exerts his limited powers to challenge a fate which spells inevitable failure; but in seeking to bury the body of another fallen hero, Antigone "destabilizes [this] tragic paradigm," as Dympna Callaghan puts it $(1989,68)$. If Antigone's fate seems a by-product of her father's misery, a kind of tragic spray, her story takes apart the values and scales Oedipus uses to judge himself guilty and correspondingly punishable. With such tools he counts on the state to protect his children, but Antigone realizes this confidence is misplaced.

Peter Krafft's painting (Figure 1) highlights the contrast between father and daughter, although it also mistakes the pain Antigone feels for Oedipus's. The woman Krafft paints covers her face but holds Oedipus's hand, her physical gesture matching the way Antigone insists on some larger history that will absorb the hero's deeds and explain their meanings-even while reminding us that ultimately everything falls within the state's purview, because ultimately everything rots. The cloud that covers the hero spares her, for although Oedipus learns who he is and why this knowledge doesn't matter, Antigone proposes that his fate is a political rather than personal one. The deaths of other tragic women similarly highlight what power expends and wastes. Misbegotten over and over, Oedipus's story unravels history and humanity, its conclusion not simply a refutation of the circumstances the hero endures, but a rejection of the larger tangle of possibility, consequence,

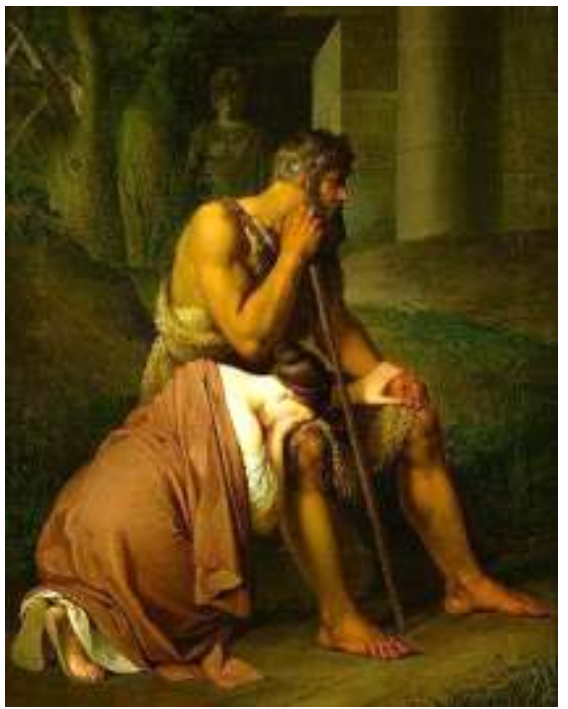

Fig. 1. Oedipe et Antigone Johann Peter Krafft [Public domain], via Wikimedia Commons https://commons.wikimedia.org/wiki/File :Oedipe_et_Antigone,_Johann_Peter_Krafft (1809).png 
and desire - what we might call culture - that makes every decision a wrong one. Oedipus discovers he's become "abhorrent to the gods" (Fagles, ed. 1. 1772), but limits the failing to his own case; convinced of her innocence, Antigone faults instead the laws that condemn and reward her with "death before [her] time" (1. 732). Heroism becomes less desirable when Antigone exposes the farce, unveiling history as an unsafe location where people only go to die. And yet, in continuing to care for her dead brother, she also holds out the prospect of some larger cosmos where people we have lost are waiting for us to join them, where blood, even when spilled, keeps flowing. She kills herself with this belief, her hanging an apt way to remind us that the air she breathes is polluted, her body also ruined by what has kept her alive. ${ }^{2}$

Like Sophocles, Shakespeare encourages us to see his female characters' deaths as more radical than men's, as political acts which reject the rules by which power works, laws order things, and lives make sense. Whether suicide, homicide, or accidents explain their ends, we can therefore group together many women who die on Shakespeare's stage as entering the realm of bios exactly when they stop living, formally indicting the world when they finally leave it behind. Suicide is the most obvious methodology, and my examination of Cleopatra, Juliet, and Goneril is the central focus, but the departures of Lady Macbeth, Ophelia, Gertrude, Hermione, Desdemona, and Regan are related gestures, and I explore them briefly as well.

Antigone comes to our notice by noticing a dead body, and Shakespeare's female suicides likewise summon our attention to the deaths of the men as signs of a world which evicts what it values. Maybe for this reason many feminist readers of Shakespeare continue to privilege male over female suffering, even when their pain is as closely linked as Sophocles and Shakespeare suggest. According to Mary Beth Rose, women "are excluded from the kind of behavior and event that both forms the heroic subject and characterizes his actions" $(1982,1))^{3}$ When they do work up the

\footnotetext{
2 Making use of the myth of the virgin killed-like Iphigenia-to save her city, Sophocles is the first playwright to present Antigone as hanging herself; in other versions of the story, she is rescued by Creon, and in some retellings, she marries Haemon. See Johnston $(2006,179)$.

${ }^{3}$ More recently Rose analyzes whether suicide involves "submissive willingness to endure death" or "aggressive self-ownership" (2016, 79).
} 
nerve, characters like Juliet display what Julia Reinhard Lupton describes as a "more secretive form of courage" "whose immediate consequence is not to expand her capacities for action but rather to sink her into a sleep like death" $(2016,287)$. Such readings strangely imply that what causes women pain exempts them from tragedy. Although she argues that tragedy "reveals the precarious status of phallic power," Callaghan finally averts her gaze, proposing that comedy remains "the preferred genre for feminist criticism" (1989, $1-4,383)$.

Other critics point to the wholescale revision of genre which female deaths can generate, but nonetheless cling to old patterns of grasping how patriarchal order is sustained or stale reasons for why this epistemological framework needs to stay put. Linda Bamber notes that women's deaths "rearrange the stories," but at the same time maintains that "women do not change in Shakespearean tragedy; they do not respond to the events of the play, to the suffering, with new capabilities" $(1982,24,8)$. We might speculate that it is precisely by leaving this world behind that female characters foist change on male characters, however. Discussing women's "borderline suicides" in Shakespeare's plays, Carol Thomas Neely suggests that female characters deliberately rewrite their stories when they choose to die. Were it not for Goneril's suicide, Neely observes, we'd have a very different world than the all-male society at the end of King Lear (1985, 103-4). Shakespeare's survivors have struck substantial compromises: their ongoing lives make us wonder whether the human subject ends up a deformed or disabled one, something an unrepentant Goneril already seems to know.

Determining to be or not to be therefore means something different when Shakespeare's female characters do the choosing. "She should have died hereafter," Macbeth laments after learning of his wife's sudden death (5.5.17), faulting both the order of the cosmos and Lady Macbeth's handling of her story when he complains about the timing of her ending. Her steady decline and eventual trance-like state suggest her death was involuntary and unplanned, as Macbeth implies, the result of sapping strength rather than evidence of newfound resolve. "What's done cannot be undone," Lady Macbeth says, stuck in sleep (5.1.46-47), possibly confirming this reading. But becoming human for the women 
Shakespeare describes involves seeking death and undoing the rules which stipulate how power should work. Agamben (2005) argues that the state fashions itself by determining which people can be left outside its laws or walls or even killed with impunity, the homo sacer a designation for those who deserve no formal protection or any official sanction of their lives (2). If Shakespeare's women often seem to occupy the empty civil space Agamben describes, their deaths are a rejection of the rules by which history, politics, and biology endow things with a vitality that ensures they will go on. For this reason Macbeth's grief at his wife's death is experienced alongside his surprise that Birnam Wood can move, his realization that the world has a map and a history outside his grasp, although the laws which give it shape can be stretched or broken by other hands. Women's suicides are simply the most radical kind of ruptures to the stories which nations and heroes tell about strength, violence, and belonging.

More explicitly than Lady Macbeth, Shakespeare's Juliet and Cleopatra reject the private realm as too narrow for the protests they want to lodge and affections they continue to cherish. Neither death disturbs a belief in a larger force that sustains things, and in her own sense of blood's magical powers Lady Macbeth shares this idea of zoe, the life force circulating outside of custom, law, and tradition. Just as the murdered Duncan's body seems to hold limitless supplies even after his death (5.1.33-34), her own ambitions can be advanced, she says, by managing blood's flow, stopping up its access, or making it thicker (1.5.40).

Lady Macbeth's discovery is a political one as well as a biological one, indicating that the differences between zoe and bios-the contrast between the energies that give things life and the force which arranges these living things into separate columns or countries or camps-can depend on whether the shedding of women's blood is something they oversee, no longer governed by natural cycles, but mobilized or militarized. In showing us female characters who approach their endings with purpose and optimism, Shakespeare thus rewrites tragedy. Laying waste to an inhospitable world and exposing the polis as a bad dream or existential cul-desac, women's speeding up of their own lives forces civilization to unravel in slow motion. Judith Butler links Antigone's challenge with a "traumatic dislocation of the polis," and we might view 
Shakespeare's female suicides as similarly pulling awry the mechanisms which hold the universe in place while also unveiling these forces as empty, false, and temporary. The next section looks for other patterns in Shakespeare's female suicides.

\section{Female versus male endgames}

Historian Michael MacDonald notes that Shakespeare's plays were produced at a time when suicides were starting to be seen as "familiar" "literary types" (1986a, 309-10). ${ }^{4}$ Previously, MacDonald adds, "there were no terms with which to describe self-destruction that did not brand its perpetrators as criminals or mad men." This finding is all the more striking because, as MacDonald also observes, most suicides were poor or female-a detail which probably accounts for the deficiency in language. Although Shakespeare doesn't glorify suicide, like other Elizabethan playwrights he also doesn't make it odious or offensive, and its occurrences on his stage after Juliet's early and repeated experiments in Romeo and Juliet emphasize a growing clarity about how and why suicidal women handle their fates. The religious picture of despair condemned suicide and limited its sorry consequences to the soul of the victim, but Shakespeare-often by allowing other characters to report the circumstances surrounding women's deaths, repositioning them as coroners at inquests - shifts his emphasis onto survivors' efforts to rationalize suicide (MacDonald 1977, 356). Although Gertrude's presence at Ophelia's drowning doesn't save Ophelia, for instance, it helps explain her. In later plays, Shakespeare represents female suicide as a deliberate act of rebellion rather than evidence of despair or depression.

It then becomes harder to fold women's ends into men's deaths, even when there are likenesses in the ways Shakespeare's male and female characters destroy themselves. Certainly, female suicides are often inspired by male examples and follow immediately after, making it tempting to construe women's deaths as offshoots or imitations - rather than deviations from those models or forms of protest which repudiate the actions of the men before them. Yet

\footnotetext{
${ }^{4}$ Elsewhere, MacDonald focuses on the early modern community's reaction to selfmurder (1986b, see esp. 53, 58).
} 
inspection reveals that Shakespeare regularly locates women who choose death close to the centers of powers that try to thwart them, representing the sad facts of diminished lives as signs of injustice and the women wounded by these conditions as not entirely defeated. Although Shakespeare's Juliet seems to join her beloved finally, for instance, any conclusion about a comic resolution makes sense only if we ignore how her death removes the last agent of renewal from Shakespeare's stage, shutting down her society's machinery for reproduction. Now at peace, Verona has room for a gorgeous statue of teenaged lovers, not because the world has been cured of its evils but instead because it's now depleted of victims; indeed, the deaths of most of the members of its younger generation suggest that this world is coming to an end. Juliet's suicide is less a gesture that mirrors Romeo's and more of a guerilla attack on the way things are, a version of the act of "subtraction" Badiou outlines. "The affirmative part of negation," Juliet's "subtraction" not only unhinges the lovers from a cruel world that insists on their separation, but also permanently rewrites the codes which made them mortal enemies in the first place.

Shakespeare presents Juliet as a kind of cosmically disturbing figure from the outset of the play, and her example supplies a blueprint for later characters who also take their lives and undo the universes they uneasily inhabit in the process. Her subtractions are introduced early on. Marriage, Juliet tells her mother, "is an honor I dream not of" (1.3.68), a statement which leaves her inner life vacant but real, with potential for something else, affirmation quickly supplanting negation, dream replacing ordinary honor. According to Badiou, "subtraction" alters the ways we are persuaded about reality, fantasy, hope, and renewal. Just as Antigone overturns her society's machinery for memory and history when she insists upon her enemy brother's rights of burial, Juliet gauges the value of living things from the perspective of the vivid dreamscape she inhabits. If Juliet not only hates her life without Romeo but despises the world, she not only kills herself because Romeo is dead, but also to avoid being "disposed," as Friar Lawrence puts it, "among a sisterhood of holy nuns." Her suicide allows her to flee yet another place of "unnatural sleep" (5.3.156) in a world where hidden places of inertia are multiple. Interestingly, Romeo has no such fears: "worldwearied," he seeks "everlasting rest" $(5.3 .110,112)$. In contrast, Juliet's taking herself out of this life has the effect of reversing its 
course and changing the map, with the result that Juliet finds her dead lover's lips still warm (5.3.167).

The significance of Juliet's suicide operates according to two principles which organize the suicides of Shakespeare's later female characters. The first rule requires us to contrast male and female deaths whenever Shakespeare links them together so closely, the way Romeo seeks rest while Juliet recreates agency. The second rule underpins what this opposition means, proposing that Shakespeare imagines a series of women opting out of damaged worlds in stories which simultaneously illustrate their insistence on a right to belong there.

Perhaps Cleopatra, the most famous of Shakespeare's suicidal heroines, challenges this reading. Little blood is involved in Cleopatra's dying, after all, and the imperial politics remain unchanged afterwards. But Egypt's queen crafts exactly when her end should happen, tapering time like one of her royal garments, "shackl[ing] accidents and bolt[ing] change" (5.2.6-7). Moreover, Cleopatra has an audience, a set of attendants, and a number of chances to make a strong finish according to her physician, "pursui[ng] conclusions infinite|Of easy ways to die" (5.2.353-54). There are other differences between Cleopatra's death and Antony's. In death, his figure is mangled, hers goddess-like, his efforts clumsy, hers expert. And Cleopatra's elaborately theatricalized exit concludes with her asking her audience to imagine her entrance elsewhere: "Husband, I come," she says (5.2.287), extracting comedy from thin Roman air and envisioning the afterlife as a place where the rites of marriage permit her union with Antony and ignore or override his bond with Octavia. Cleopatra can simply abandon the old world and her children and their future, neatly absenting herself from a limited place instead of repairing or enlarging it. No wonder Caesar celebrates the way her death cements his authority, concluding that Antony and Cleopatra's story is "No less in pity than his glory which | Brought them to be lamented" (5.2.359-61).

In contrast with Cleopatra's rejection of Caesar's universe is Badiou's idea of negation, which imagines the "complete disintegration of an old world," making possible in turn "something which exists absolutely apart from what exists under the laws of what negation negates." Cleopatra's ambitions also pale next to Juliet's. The Egyptian queen chooses myth-making over politics, 
escape over war, and happiness over protest. Juliet's vision, instead, is consistently morbid. Even on a good day, she sees Romeo as a corpse (3.2.22), and her habits routinely subvert the steps Shakespeare takes to present his tragic heroes-with the notable exception of Antony - as vital, athletic, healthy, ready to wage war, not to lie down. Hamlet's death first involves a crowd-pleasing duel with Laertes, and Romeo's death follows a similar display with Paris. When female deaths happen alongside these heroic male examples, they also rudely marginalize them. Finding that Romeo has drained the cup of poison, for instance, Juliet appropriates his sword, suggesting his purchase from the apothecary was unnecessary and her own experiments with Friar Lawrence's potions emboldening. She parts company from Romeo when she commits suicide right after he does, highlighting his despair, foregrounding her frustration. He is disheartened, she is impulsive, he thinks she's dead, she knows he is. ${ }^{5}$ Heath's engraving (Figure 2) suggests that it is this knowledge in fact which awakens Juliet.

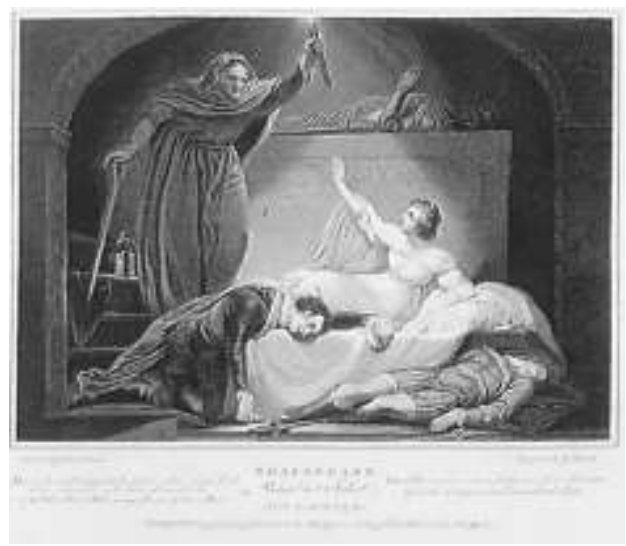

Fig. 2. Juliet awakes, and finds Romeo dead. Engraving by James Heath (1757-1834) after painting by James Northcote (1746-1831). [Public domain], via Wikimedia Commons. https://commons.wikimedia.org/wiki/File:Northcote-JulietAwakes.jpg

5 Recent readings of Romeo and Juliet examine the lovers' preference for heteronormative sameness and staleness; see, for instance, Schwarz (2016). But such readings still link Romeo and Juliet together, even when death-like banishment or sleep-divides them, even when Shakespeare puts Paris in the grave with them. See Freccero, who highlights the play's "driving negativity" and "formal and thematic investments in failure" (2011, 304, 302); and Stockton (2016, esp. 298-301). 
Other female suicides on Shakespeare's stage follow Juliet's subversive example. Marion Wynne Davies contrasts the ugly picture of rotting skulls in Hamlet with the appealing image of the drowned Ophelia, her flesh not only undefiled but preserved and exposed, "fair and unpolluted" (5.1.222). Women's bodies appear to withstand death (Wynne-Davies 2012, 155, 160), a disparity which Juliet highlights when she drinks the potion and anticipates the "chapless skulls" in a "charnel-house" she will soon encounter, even as she decorously outfits herself in sleep (4.1.83). We hear that the dead Cleopatra is still entrancing enough to catch another Antony (5.2.336-37). Gertrude, a witness to Ophelia's drowning, later reports to Laertes a painless process of extraction which only increases Ophelia's resemblance to "a creature native and endued | Unto that element" (5.1.15051). Yet Gertrude also makes clear that Ophelia's death-which Gertrude nowhere describes as a suicide-was anything but accidental. The circumstances are muddy, but Gertrude orients us with a detailed picture of a protracted descent. Had she saved Ophelia's life-a possibility other scholars float in noting Gertrude's presence at the "glassy stream" and proximity to the victim-Gertrude would've stolen Ophelia's crowning achievement, a self-murder that puts the blame for Ophelia's losses on a corrupted state ruled over by a failed king. ${ }^{6}$ Gertrude later approaches her own death with similar calm and precision, drinking from the cup her husband warns her not to touch, finishing off its contents while letting Hamlet see the extent of Claudius's lethal ambitions. "The drink, the drink -I am poisoned," she makes sure Hamlet knows (5.2.254). Hamlet's father accused Claudius of murder, but Gertrude insists Hamlet witness it. Taking for herself the drink set out for a reluctant hero, Gertrude also rewrites the end of Romeo and Juliet's sad story, parting company with Hamlet when she finishes the poison before he can, neatly tearing a hole in the revenge plot by revealing the ruthlessness of Claudius and Hamlet as comparatively messy.

Desdemona takes advantage of a similar opportunity to rewrite history and release Othello from his tortured positioning there when she absolves him of her death and claims her murderer was "Nobody, I myself" (5.2.133). Representing her end as a suicide and simultaneously giving herself power in a world that takes it away

${ }^{6}$ Gallagher (1995) and Ratcliffe (1998) explore Gertrude's possible complicity. 
from its guardians and warriors, Desdemona directs violence at Othello's ethos when she aims it at herself. Hermione's feigned death in The Winter's Tale-another faux suicide? - works the same way. ${ }^{7}$ She withdraws from Sicilia at the news of Mamillius's death and eventually returns as a statue, showing anyone who cares to look that what preserves her embalms her, what sustains the world cuts breath and transforms her to stone. ${ }^{8}$ Her "warm life," which now "coldly stands," reappears to "rebuk[e]" her husband (5.3.3436). The "small wars" which Shakespeare's women seemingly wage against themselves are undertaken in order to challenge the cosmic order. ${ }^{9}$ They are battles which unsettle the lines between the living and the dead, disrupt the practices of slippage or catechresis, and enlarge the conditions under which people can count.

\section{Is this the promised end? or image of that horror?}

The standard reading of tragedy which centers on the death of the noble male figure contributes little to our reading of female deaths, and perhaps explains why we view so many female suicides as "botched," the rites surrounding women's passing and burial similarly "maimed." Ophelia's exit might seem particularly incoherent, the workings of bad luck dampening her motives. Ophelia slips and falls from a riverbank, her costume too heavy, her lunacy a drag, so that even though she fashions garlands from Denmark's "unweeded garden," her misery gets caught on psychological symptoms which undercut her agency. How different appears the death of Lear's evil Edmund, who makes his exit publicly announcing he was loved, with Shakespeare's audiences registering this fact. Edmund's epiphany has value, such that the world is made whole again, its intactness verified. But women's deaths instead underscore how little is assured about their fates their control of their bodies, their security or habitation of private spaces, their opportunity to explain themselves to others. Perhaps women's stories are those of incipient beings, partial persons, potential

\footnotetext{
7 Neely not only refers to Hermione's "strategic mock death" $(1985,5)$ but also suggests Desdemona's actual death resembles other "mock deaths" (125).

8 Waldron explores these frustrated gestures to categorize women "as dead or alive" (2012, 205-6).
}

${ }^{9}$ I borrow the phrase from the title of Scheper-Hughes and Sargent's 1998 collection. 
people whose self-murders provide ways to live and to die at the same time. ${ }^{10}$ Certainly the anguish surrounding Lady Macbeth's death is deepened by confusion over her status as a living thing, as Macbeth's strained eulogy also reminds us. Her unusual powers of vitality have always been located alongside remissions of feeling, her pledge to love her husband made against the specter of her murdering their unborn baby, her tenderness a prelude to dashing out its brains (1.7.58). Not everyone gets to survive or flourish, Lady Macbeth tells us, loving something not a guarantee of its worth or permanence or existence on any solid ground.

Like a riot or act of terror or the image of infanticide which Lady Macbeth lovingly shares with Macbeth, female suicides outline a subtraction which Shakespeare refines over time, allowing him to outline other ways female deaths are different from men's, more important or revolutionary, and more public and political in their aims, methods, and consequences. In Romeo and Juliet an abandoned woman decides to embrace her detachment from the rest of the world, and Shakespeare continues to reimagine female self-murder in Hamlet and in King Lear, both plays charting this expanded perspective. Although a hostile world provides the background in these plays, too, our sympathies with the female suicide change, for instance, the longer a female character lives with the ignoble awareness that in some ways she is already dead. There are some constants. Like Juliet, Gertrude and Goneril take their societies prisoner at their deaths: their suicides are political and public rejections of energy, love and bios. Like Antigone, too, all three women reject grief. Yet the differences in their examples are equally interesting. Juliet refuses the state, its promises of belonging; Gertrude rejects its habits of renewal and rites of memory; but Goneril overturns its tools for identification, habitation, devotion, revenge, and euthanasia.

Juliet, Gertrude, and Goneril also speed up chronology, making the conclusions of their stories something they consciously confront, easy to see. Rather than taking up arms against a sea of troubles, they collapse the moral and logical structures which consign women to the roles of mourner, witness, and mother. Butler describes

\footnotetext{
10 The phrase partial person characterizes another category in the spectrum of what comprises the human, roughly applicable to the fetus or to the comatose patient. See Morgan (Scheper-Hughes and Sargent 1998, 68-72).
} 
Antigone as someone for whom "symbolic roles have become incoherent" (2000, 22), and Goneril similarly wishes to revise the codes which explain her life, not only rejecting her husband's love but also faulting his ethos when she tells him his "text is foolish" (4.2.38). Juliet rejects such scripts, too. All of the time she spends sleeping, feigning death, or concealing herself among corpses likewise underscores how little women are supported by the frameworks that order their existence and regulate their place. Although classical historian David Daube describes this imperiled condition as one that isolates Oedipus, for whom death is less of a solution than never having been born in the first place, Antigone's example undercuts Daube's observation, because she views survivors and the dead as analogously victimized. The world seems smaller in the wake of such discoveries. Yet if we wonder what sustains female lives in an environment which appears not to need them, we still might ask what finally pushes them out, when nothing is really beckoning them beyond? In the next section I examine how Juliet, Gertrude, and Goneril plan their escapes.

\section{Little stars}

Juliet never overlooks a chance to do battle with the rules that would keep her and the things she loves hidden or unfree. Even when she says farewell to Romeo, she pries the darkness that surrounds them open: "Methinks I see thee, now that art so low, | As one dead in the bottom of a tomb" (3.5.55-56). She is prepared to kill herself in Act 4, long before the friar gives her a potion: what happens in the interval between brandishing a knife in his cell and plunging it into her heart a few scenes later only affords Juliet more time to imitate death or pretend to sleep. Her suicide is of a piece with the rest of her ethos, her framework for life wide enough to make self-destruction something viable. Friar Lawrence gives her the sleeping potion after seeing Juliet's resolve: "If, rather than to marry county Paris, | Thou has the strength of will to slay thyself, | Then it is likely thou wilt undertake | A thing like death to chide away this shame" (4.1.71-74), he says.

That Juliet knows how tenuous her own status might be is part of her charm for Romeo, but it also suggests we reconsider her many decisions to take her life, or at least view her rebellion as 
philosophical rather than hormonal. "Bondage is hoarse," she admits, "and may not speak aloud" (2.1.205-6), but Juliet is determined to flee the custody of her parents and nurse, lover, and confessor. Agamben (1993) claims the overthrow of such hard conditions is something heroic, joyful, exhilarating. Yet running away would leave the conditions of the world unchanged, so Juliet stays in Verona instead of fleeing with Romeo to Mantua. Playing with the powers that keep her alive-which weaponize the young and turn Verona's streets into war-zones-ultimately furnishes a better way to expose and disarm a totalizing system.

Maybe then Juliet is being coy in calling the death she seeks a "restorative" (5.3.166). Flirting with the poisoned cup and unsheathed sword, she uses them (the way she's used Romeo?) to avoid a fate sealed for her by "a greater power than [she] can contradict" (5.3.153). She rejects the hard limits of her life as well as the arbitrary rules dividing living things from dead things, separating Juliet from her lover as well as from everyone else. Indeed, Juliet has been working on repairing ontology when we first encounter her. If she exclaims upon meeting Romeo that her "grave is like to be my wedding bed" (2.1.132) and then faults him for "kissing by the book" (1.5.107), she also subverts taxonomies when she substitutes a lark for the nightingale (3.5.2) to exchange night for day. In her slow but steady progress to the Capulet tomb, Juliet becomes proficient in techniques for extinction, burial, and reclassification. The reordering she performs is neat and clean, zoe put to use rather than pushed outside: "My only love sprung from my only hate" (2.1.135) she calls Romeo, and later she says he is a "Beautiful tyrant, fiend angelical" (3.2.75).

Because the lines distinguishing bios and zoe get redrawn by Juliet's perceptions, she can also reconfigure the difference between adulthood and burial, wisdom and imperturbability, unconsciousness and immolation. "Bid me go into a new-made grave | And hide me with a dead man in his tomb," she proposes at another point, detailing a vision that links her with her beloved but permanently severs her from him, too. In the same way, Juliet's blazon for Romeo also drastically dissects the landscape: "Give me my Romeo, and when I shall die | Take him and cut him out in little stars, | And he will make the face of heaven so fine| That all the world will be in love with night | And pay no worship to the garish 
sun" (3.2.21-25). Cleopatra sees Antony as a god, superhuman and dolphin-like (5.2.98), an emperor whose huge size is the best way to convey his power, his sway. But Juliet mixes Romeo up with everything else, a cosmic upset that transforms the universe rather than hogs up space. Antony casts a big shadow; Romeo makes all shadows disappear. In a world in love with night, no one else need be lost or find herself excluded. If suicide supplies another way to make bios equal to zoe-ordering things a way to illuminate them -it also gives women an opportunity to reject their place on the Great Chain of Being along with the chance to take it down.

This goal encourages Shakespeare to play with generic boundaries in Romeo and Juliet, shifting between tragedy and comedy, making escape as necessary and as irresponsible as falling in, staying home, or growing old. Lee Edelman likens this project to the death drive Derrida describes, "conjured" to "conjure away the norm" (2011, 149, 53n4), although such activities are undertaken regularly nowadays through organ donations and stem cell transplants which redraw the lines marking off who lives from who can die. Suicide assumes its place as another way to re-engineer the polis, the person who undertakes it an irritant or exception "without which the polis could not be" (Butler 2000, 4), but also the person with whom a new polis might arise.

\section{Maimed rites and disabled selves}

In his catalog of conjurings, Edelman points to Hamlet as a queer subject, an example of those who are abjected, "non-reproductive, anti-social, opposed to viability" $(2011,148)$. But Edelman curiously neglects the examples of Ophelia and Gertrude, even though they both refuse the cycles of renewal which Hamlet also disowns. Emily Bartels investigates this elision, describing how women in Shakespeare's plays guarantee male identity but lack identity themselves, Ophelia's burial less a tribute to her memory than an excuse for two displaced noblemen to identify themselves in mourning her. Yet Hamlet's reworking of Antigone's plot, in which the heroine balances the claims of two of the polis's enemies, makes these male characters' status dependent on Ophelia's rebellion.

Moreover, Ophelia's multiple affiliations challenge Hamlet's assumptions that identity is bestowed, not forged, and that there can 
only be one lawful memory or set of loyalties. Although Bartels emphasizes how women are merely conduits for genealogy in Hamlet, just as important is the play's insistence that access to power is restricted to a single contender in a contest that punishes other claimants $(2016,198-99,203)$. Ophelia prefers to keep these channels open and competing histories alive, telling her brother "you must wear your rue with a difference" (4.5.179), remembering and mourning in new ways. The audience thus helps with Hamlet's obsessive housekeeping when it pushes Ophelia's plight away out of view, turning it into a private grief, restricting it to something the state can safely ignore. Ophelia's death uncovers fissures in being that Hamlet's philosophy thinks it can negotiate, her life a tangle of precepts, her affections deadly, her place in the larger world untenable, shaky-or, maybe, as Gertrude puts it, "Mermaid-like" (4.7.174). No wonder the creature represented in Burthe's painting (Figure 3) holds onto a branch for support so needlessly, the water uplifting, her body in no real danger.

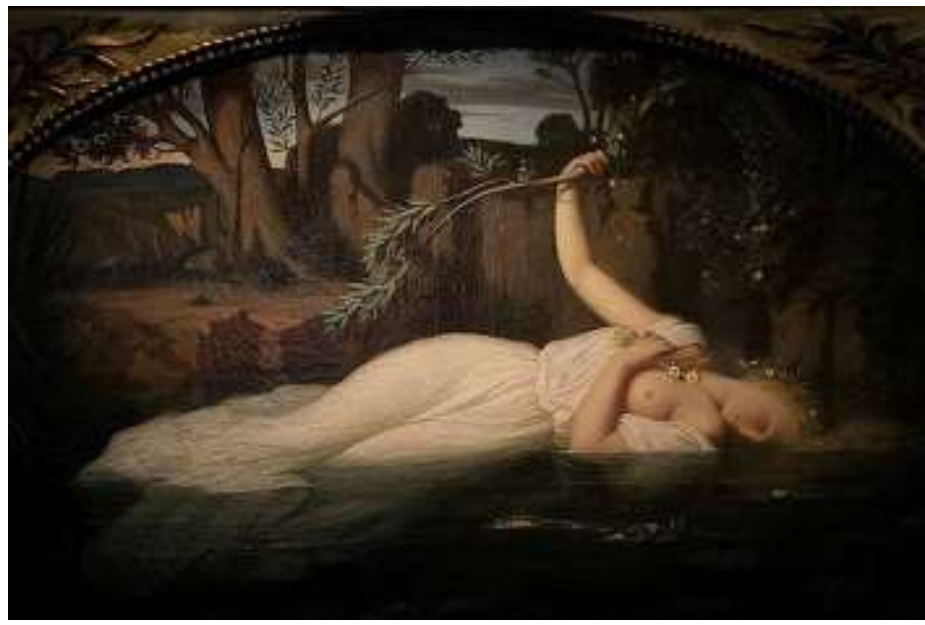

Figure 3. Ophélie. By Léopold Burthe (1823-1860). [Public domain], via Wikimedia Commons

https://commons.wikimedia.org/wiki/File:Oph\%C3\%A9lie_de_L\%C3\% A9opold_Burthe1.jpg (http://leilaamat.com/ophelia-de-leopold-burthe

Contemporary sociologists exploring the motives of female suicide bombers uncover a similarly dense and contradictory web of ties and motives. One study quotes the "mission" of a "fervent nationalist" who states: "I have witnessed the calamity of my people 
under occupation. With total calmness I shall carry out an attack of my choice [...]. I hope my soul will join the souls of other martyrs [...] I am now planted in the earth of the South irrigating and quenching her with my blood and my love for her." 11 This statement combines the language of maternity with a rhetoric of sacrifice, despair, and hate in the same way Lady Macbeth's speech does, her florid discourse competing with her wish to decimate reality. There is no new place created by such upheaval, no new homeland awaiting the terrorist's return. The female terrorist's private pain stems from and recreates wider deprivations, just as Lady Macbeth's dreams of power first require her to see her body as poisonous.

Under similar conditions, Ophelia becomes "incapable of her distress" (5.1.148), stuck in infancy and deprived of history. András Kiséry recently describes Ophelia as "a body spoken for and by the male agents of political change," rightly noting that Laertes is fomenting rebellion well before he reunites with his sister at Claudius's court (78). Ophelia's violation is represented by readers like Kiséry as a personal rather than a political crime, a secret which cannot be shared even when it is known. According to Kiséry, Ophelia's "suffering and death seem to be gesturing at a partisan agenda but end up strongly refusing to align with it" $(2017,79)$. The suicide bomber's destructive impulses similarly frustrate us, but this confusion might be another intended effect, the result of a political agenda.

Gertrude's act of witness guarantees that Ophelia's death is a public act, successfully pushing male agents of change to destroy each other while offering a model for Gertrude to follow later. When the clowns report that Ophelia "drowned herself wittingly" "in her own defense" $(5.1 .12,5-6)$, they duplicate Gertrude's representation of self-murder as the rejection of a criminal world. Gertrude will adhere to this script in draining the cup meant for her son. As Neely puts it, Ophelia's "borderline suicide" "prefigures Gertrude's later death" when she disobeys Claudius's command, drinks from the poisoned cup, and "withdraw[s] from the wifely role she has

\footnotetext{
${ }^{11}$ Jacques and Taylor maintain that women terrorists "hold more complex, dualistic reasons for their involvement, combining collective motivations such as a desire for national independence with individualistic motivations such as the desire for equality between the sexes" $(2008,305)$. Badiou points to the martyr's hope for changing the world supplied within "the religious context of terrorism."
} 
acquiesced in throughout" (1985, 103-4). ${ }^{12}$ A larger social failure connects these events, just as the senseless deaths of Romeo and Juliet signal corruption in Verona. Indeed, when Laertes sees Gertrude's corpse he places himself alongside it with the announcement: "Lo, here I lie, | Never to rise again | Thy mother's poisoned.| I can no more. The King, the King's to blame" (5.2.26163). Duplicating the image of an aggrieved woman taking her life offers a way for Shakespeare to elevate Laertes' and Hamlet's ambition and misery and thereby radicalize their despair.

\section{Yours in the ranks of death}

Goneril's suicide has generated less attention than the deaths of Ophelia and Juliet, for they are treasured daughters whose marriageability is construed as a tool to guarantee the future of their worlds. In contrast, Goneril scandalizes the home and its promises of renewal, placing the distaff in her husband's hands and treating her position as daughter and wife as roles to exploit or abandon. At the same time, however, Goneril grounds her identity in repeated claims that she is a partial person, as we see in her strict surveillance of her staff and in her competition with Regan. Her profession of love for Lear disables her too, saying her affection is "Dearer than eye-sight, space, and liberty" (1.1.54). Goneril finds community in suffering, and even intimacy in "the ranks of death" (4.2.24). Regan merely copies Goneril's degradations. "Prize me at her worth" (1.1.69), Regan tells Lear, but unlike Goneril, Regan seems "incapable of her distress" or of doing without the supports Goneril ranges against each other. Goneril entrusts Oswald with her letters and her secrets, for instance, while Regan merely tries to pry him open; Regan desires Edmund, Goneril actually kisses him; Goneril insists on order, Regan only sees imbalance. "One side will mock another" (3.7.72), Regan tells Cornwall, demanding he gouge out both of Gloucester's eyes, her sense of justice verified by agony. As Edwin Abbey's painting uncovers (Figure 4), Regan is only part of a partial person, filling the leftover space where her "sister comes too short" (1.1.71). Goneril shows compassion for her sister's plight, however. Although Antigone abandons Ismene in killing herself, Goneril

${ }^{12}$ For similar readings, see Ratcliffe (1998, 125-26); and Gallagher (1995, 526, 534). Rose claims Ophelia's death, like that of Lady Macbeth, may be a suicide $(2016,75)$. 
ensures that Regan dies with her. The sympathy Goneril extends Regan relinquishes one vision of the future for another, where eyesight, space and liberty might be somehow rendered more dear.

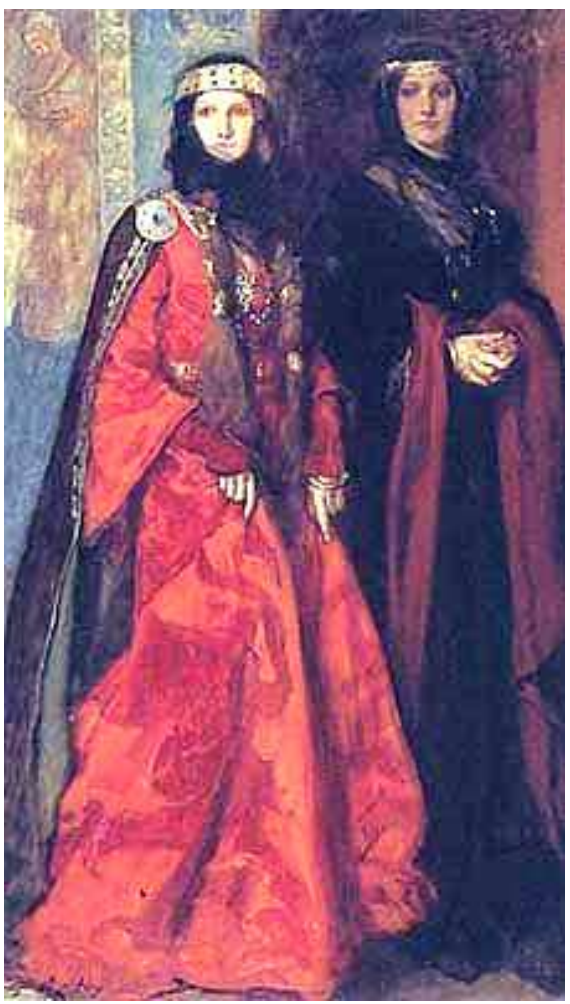

Figure 4. Goneril and Regan from King Lear. Edwin Austin Abbey [Public domain], via Wikimedia Commons https://commons.wikimedia.org/wiki/File: Goneril_and_Regan_from_King_Lear.jpg
Goneril extends other kindnesses. She uses the poisoned cup featured both in Romeo and Juliet and in Hamlet against her sister rather than stabs Regan - the other method employed in both of these plays-because Goneril wants Regan to see what isn't there, what Lear's love test and Cordelia's harsh refusal have put into relief, that promises of belonging and connection in this play are premised on weakness and imprisonment. We might even imagine Goneril as providing a moral and ontological rescue similar to Edgar's pulling Gloucester from the brink of the cliff, forcing him to see what's not there. Goneril gives Regan's paltry desires weight by blocking them entirely. Her own death immediately afterwards then shuts down the private realm as dreary and unsafe.

\section{Conclusion}

There are more recent examples of such deadly agents in the profiles of female soldiers collected in Svetlana Alexievich's extraordinary oral history The Unwomanly Face of War (2017), where women put themselves under similar pressures to change the stories of their lives. These female soldiers head to the front with the unshakable 
idea of a utopia worthy of their efforts, believing they are the equals of their fathers, husbands, and brothers, just as capable of driving tanks, lobbing grenades, and firing unerringly at their enemies. But these female soldiers also share the radical idea that the horrors of battle and shedding of blood can remake the world, not destroy it. Even the terrible loss of people whom these women love does little to diminish the feeling that there are other generative powers in the universe, other ways to keep life going, other ways to set things right. One woman reports how she "felt like buying pair of shoes" while her unit was retreating, "elegant little shoes" along with some perfume (53); pain brings second chances, another female soldier confirms, telling Alexievich how she "like[d] herself so much" in a "wedding dress" fashioned from bandages she and her fellow soldiers had spent a month collecting (238). In both of these examples, renewal has nothing to do with signing up for the same but is bound up, instead, with killing. The impulse these women describe is a queer one, sidestepping reproduction but also tampering with the economy which spells out the worth of female lives and the uses to which they can be put. In this economy, self-effacement serves as a way to be in charge, a way to deploy authority if not to have it.

Like the figures of Antigone and Shakespeare's female suicides, the lives of these soldiers can make the most sense when they die. Callaghan points out a similar irony in proposing that " $[\mathrm{w}]$ oman has a unique and crucial relation to tragedy. Her death undermines notions of transcendence so beloved of humanist criticism [...] [her] transgression does not bring the downfall of humanity but [...] discloses the limitations of moral and social codes" (1989, 96-97). In such a constrained universe, choosing is always a punishing activity, something another one of Alexievich's subjects underscores in a story of beginnings and endings which, ultimately, confounds them. At one point during the war, this woman, a radio operator who had recently given birth, was hiding from the enemy with her baby and other members of her unit. Concealed in a swamp, they find themselves surrounded by "punitive forces" when the baby begins to cry. As the enemy approaches, "no one can give the order," but this woman "figures it out herself" and "lowers the baby and holds it there for a long time," until the child's crying stops. In a world where only death ensures life, acts of love are hallowed by acts of 
hate. Turning one's face from the gaze of the child provides another way to have a future, to keep life going.

Lady Macbeth likewise refuses her nursing child, but Gertrude takes the cup from her son and chooses death for herself alone, rewriting the future as a place without her. Possessed by the same "feral thoughts" which Robert Burton enumerates in his Anatomy of Melancholy (1621), other women on Shakespeare's stage assert themselves in worlds whose rationales they reject (qutd. MacDonald 1977, 366). "Feral thoughts" overturn feral worlds. Long before Agamben (1998) argues that modern man is an "animal whose politics call his existence as a living being into question" (3), Antigone reminds us that the need to join the political sphere is undercut by the discovery that nothing worthwhile happens there. Shakespeare's dying women share this understanding that redemption is impossible unless the body politic disappears and renewal is banished, at least from inside the home. Refusing to be grounded there, such female figures trade their small place in history for some wider cosmic expanse.

In this way Shakespeare also proposes that the face of the future is not the innocent unborn child but the strong woman tough enough to let it go, who insists that there is more to life than its reproduction. In contrast with the deaths of Antony, Romeo, and Hamlet, whose departures gracefully make room for other heroes and other histories, the lives and deaths of such women are finally pitiless. "Cover their faces," Albany commands at the end of King Lear (5.3.255), concerned that the mortifying bodies of Regan and Goneril be concealed from us. Blocked from view, we cannot be sure of who these women are, even in their deaths. But it's possible that more than the fates of the little star Romeo or sweet prince Hamlet or Emperor Antony - the influence of female characters who find ways to end their stories remains magical and poisonous, unvanquished and kindling, still transformative, still alive.

\section{References}

Agamben, Giorgio. 1993. Infancy and History: On the Destruction of Experience. Translated by Liz Heron. New York: Verso.

Agamben, Giorgio. 1998. Homo Sacer: Sovereign Power and Bare Life. Translated by Daniel Heller-Rozen. Stanford: Stanford University Press. 
Agamben, Giorgio. 2005. State of Exception. Translated by Kevin Attell. Chicago: University of Chicago Press.

Alexievich, Svetlana. 2017. The Unwomanly Face of War: An Oral History of Women in World War II. Translated by Richard Pevear and Larissa Volokhonsky. New York: Random House.

Badiou, Alain. 2007. "Destruction, Negation, Subtraction-on Pier Paolo Pasolini." Graduate Seminar Art Center College of Design in Pasadena. February 6, 2007. Accessed June 27, 2019.

https://www.lacan.com/badpas.htm.

Bamber, Linda. 1982. Comic Women, Tragic Men: A Study of Gender and Genre in Shakespeare. Stanford: Stanford University Press.

Bartels, Emily. 2016. "Identifying the Dane: Gender and Race in Hamlet." In The Oxford Handbook of Shakespeare and Embodiment, edited by Valerie Traub, 197-201. New York: Oxford University Press.

Butler, Judith. 2000. Antigone's Claim: Kinship between Life and Death. New York: Columbia University Press.

Callaghan, Dympna. 1989. Women and Gender in Renaissance Tragedy. Atlantic Highlands, NJ: Humanities Press.

Daube, David. 1983. “Black Hole.” Rechtshistorisches Journal 2: 177-93.

Edelman, Lee. 2004. No Future: Queer Theory and the Death Drive. Durham: Duke University Press.

Edelman, Lee. 2011. "Against Survival: Queerness in a Time That's Out of Joint." Shakespeare Quarterly 62 (2): 148-69.

Esposito. Roberto. 2004. Bios: Biopolitics and Philosophy. Translated by Timothy Campbell. Minneapolis: University of Minnesota Press.

Freccero, Carla. 2011. "Romeo and Juliet Love Death." In Shakesqueer: A Queer Companion to the Complete Works of Shakespeare, edited by Madhavi Menon, 302-8. Durham: Duke University Press.

Gallagher, Lowell. 1995. "Mise en Abyme, Normative Subjectivity, and the Ethics of Mimesis in Hamlet: Gertrude Talks." Genre 28 (2): 513-41.

Jacques, Karen, and Paul J. Taylor. 2008. "Male and Female Suicide Bombers: Different Sexes, Different Reasons?" Studies in Conflict and Terrorism 31: 304-36.

Johnston, Sarah Iles. 2006. “Antigone's Other Choice.” Helios 33: 179-85.

Kiséry, András. 2017. Hamlet's Moment: Drama and Political Knowledge in Early Modern England. New York: Oxford University Press. 
Lupton, Julia Reinhard. 2016. "Public Women/Women of Valour." In Shakespeare in Our Time., edited by Dympna Callaghan and Suzanne Gossett, 285-88. New York: Bloomsbury.

MacDonald, Michael. 1977. "The Inner Side of Wisdom: Suicide in Early Modern England. " Psychological Medicine 8: 565-82.

MacDonald, Michael. 1986a. "Ophelia's Maimed Rites." Shakespeare Quarterly 27 (3): 309-17.

MacDonald, Michael. 1986b. "The Secularization of Suicide in England, 1660-1800." Past and Present 111: 50-110.

Morgan, Lynne M. 1998. “Ambiguities Lost: Fashioning the Fetus into a Child in Ecuador and the US." In Small Wars: The Cultural Politics of Childhood, edited by Nancy Scheper-Hughes and Carolyn Sargent, 58-74. Berkeley: University of California Press.

Neely, Carol Thomas. 1985. Broken Nuptials in Shakespeare's Plays. New Haven: Yale University Press.

Ratcliffe, Stephen. 1998. "What Doesn't Happen in Hamlet: The Queen's Speech." Exemplaria 10 (1): 123-44.

Rose, Mary Beth. 1982. Gender and Heroism in Early Modern English Literature. Chicago: University of Chicago Press.

Rose, Mary Beth. 2016. "Suicide as Profit and Loss." In Shakespeare in Our Time: A Shakespeare Association of America Collection, edited by Dympna Callaghan and Suzanne Gossett, 73-80. New York: Bloomsbury.

Scheper-Hughes, Nancy, and Carolyn Sargent, eds. 1998. Small Wars: The Cultural Politics of Childhood. Berkeley: University of California Press.

Schwarz, Kathryn. 2016. "Comedies End in Marriage." In The Oxford Handbook to Shakespeare and Embodiment, edited by Valerie Traub, 267-86. New York: Oxford University Press.

Shakespeare, William. 2015. The Norton Shakespeare. Edited by Stephen Greenblatt, Walter Cohen, Jean E. Howard, Katharine Eisaman Maus, Gordon McMullan, and Suzanne Gossett. New York: Norton.

Sophocles. 2000. Three Theban Plays. Edited by Robert Fagles. New York: Penguin.

Stockton, Will. 2016. "The Fierce Urgency of Now: Queer Theory, Presentism, and Romeo and Juliet." In The Oxford Handbook of Shakespeare and Embodiment, edited by Valerie Traub, 297-301. New York: Oxford University Press.

Waldron, Jennifer. 2012. "Of Stones and Stony Hearts: Desdemona, Hermione, and Post-Reformation Theater." In The Indistinct Human in 
G)edri 29 (2019)

Renaissance Literature, edited by Jean E. Feerick and Vin Nardizzi, 204-27. New York: Palgrave.

Wynne-Davies, Marion. 2012. “Ophelia's Ghost." Alicante Journal of English Studies 25: 151-66.

How to cite this article:

Mazzola, Elizabeth. "Suffocated mothers, stabbed sisters, drowned daughters: when women choose death on Shakespeare's stage." SEDERI 29 (2019): 109-33.

https:/ / doi.org/ 10.34136/ sederi.2019.5

Author's contact: emazzola@yahoo.com

Postal address: English Dept. - The City College of New York - 160 Convent Avenue New York, NY 10031 - USA

Submission: 12/03/2019

Acceptance: 25/3/201 